\title{
Staphylococcal infection of a left ventricular aneurysm
}

\author{
IAN R STARKEY, DAVID K KAPLAN, J ANDREW C THORPE \\ From the Cardiothoracic Unit, Northern General Hospital, Sheffield
}

Left ventricular aneurysm formation is a common complication of myocardial infarction. Depending on the definition used, the incidence in survivors of acute myocardial infarction is between $4 \%$ and $40 \%$, with mural thrombi present in about half of all aneurysms. ${ }^{1}$ Infection of these thrombi at times of bacteraemia might be expected to occur quite commonly but has been described only occasionally. We present such a case and review previously reported cases.

\section{Case report}

A 55 year old man was admitted to hospital 24 hours after the development of severe left pleuritic chest pain, delirious and with a pyrexia of $42^{\circ} \mathrm{C}$. He had been admitted to a coronary care unit 11 weeks previously with an acute anterior myocardial infarction; after three days a pericardial friction rub was noted and his recovery was complicated by a moderate degree of cardiac failure requiring treatment with a diuretic. He had been discharged home after one week and remained well, apart from atypical exertional chest pain relieved by rest.

On examination he was toxic with a tachycardia of 130 beats/min, small volume peripheral pulses, and a blood pressure of $90 / 70 \mathrm{~mm} \mathrm{Hg}$. There was clinical cardiomegaly with paradoxical pulsation superior to the cardiac apex. Auscultation revealed a loud third heart sound but no cardiac murmurs. The jugular venous pressure was raised and auscultation of the chest revealed bilateral basal crepitations. There was no evidence of focal infection or any peripheral stigmata of infective endocarditis.

Investigations yielded the following results: haemoglobin concentration $12.3 \mathrm{~g} / \mathrm{dl}$, white cell count $17.8 \times 10^{9} / 1$, erythrocyte sedimentation rate $79 \mathrm{~mm}$ in one hour, blood urea concentration $10.4 \mathrm{mmol} / 1(61.2 \mathrm{mg} / 100 \mathrm{ml})$, and normal electrolytes. Blood cultures grew Staphylococcus aureus. The electrocardiogram showed changes of extensive anterior myocardial infarction with persistent ST elevation and left axis deviation. The chest radiograph showed changes of pulmonary venous congestion and cardiac enlargement with a bulge on the left heart border suggestive of a left ventricular aneurysm.

Address for reprint requests: Dr IR Starkey, Northern General Hospital, Sheffield S5 7AU.

Accepted 9 September 1985
Appropriate parenteral antibiotic treatment was started and the patient's temperature and mental state rapidly re $=$ turned to normal. He remained hypotensive with poor uring output and was transferred to the regional cardiothoracig centre. A two dimensional echocardiogram was performed? which confirmed the presence of a large anteroapical ventricular aneurysm and had appearances suggesting thrombuo within. Shortly afterwards he had a recurrence of severe lef? sided chest pain and examination revealed a loud pleuê ropericardial rub. Emergency surgery was advised withour any further investigation.

At operation the pericardium was found to be denselgo adherent to an anteroapical left ventricular aneurysm $12 \mathrm{~cm}$ in diameter. On mobilisation it was apparent that both true and a false aneurysm, each with thrombus within, were present and in communication with each other (figure) When the false aneurysm was entered $150 \mathrm{ml}$ of pus (culture of which grew Staphylococcus aureus) was aspirated from and abscess cavity within the thrombus. Both the true and the false aneurysms were excised and the ventricle was close $\Phi$ between Teflon buttresses. The patient came off cardio 3 pulmonary bypass easily with no inotropic support. The pericardium was washed out with $1 \mathrm{~g}$ of cloxacillin and the. chest closed in routine fashion. The patient continued tor have parenteral antibiotics for 10 days. After he had stopped

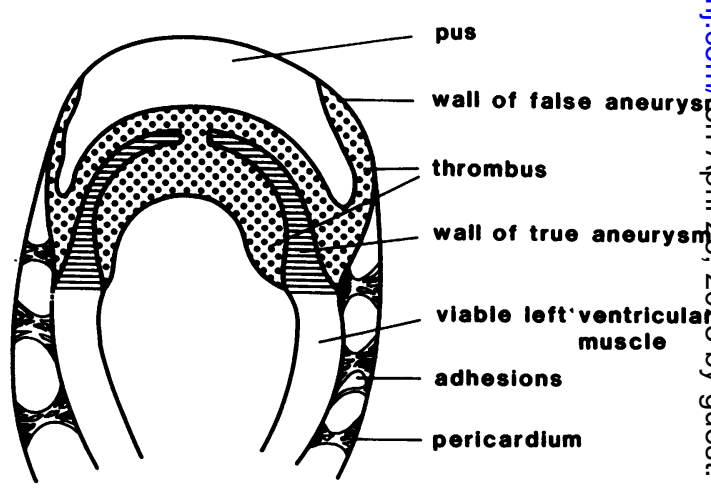

Diagrammatic representation of the operative findings, showing true and false left ventricular aneurysms, each with thrombus within, and an abscess cavity within the false aneurysm. 
Clinical details of present and previous cases of infection of a left ventricular aneurysm

\begin{tabular}{|c|c|c|c|c|c|c|c|}
\hline $\begin{array}{l}\text { Refer- } \\
\text { ence }\end{array}$ & Age/Sex & $\begin{array}{l}\text { Time } \\
\text { from } M I\end{array}$ & Symptoms & Organism & Source & Method of Diagnosis & Outcome \\
\hline (Present & $55 \mathrm{M}$ & $11 \mathrm{w}$ & Fever Left chest pain & Staphylococcus aureus & $?$ & Surgery & Alive \\
\hline $\begin{array}{l}2 \\
3 \\
4\end{array}$ & $\begin{array}{l}54 \mathrm{M} \\
53 \mathrm{M} \\
53 \mathrm{M}\end{array}$ & $\begin{array}{r}11 \mathrm{w} \\
3 \mathrm{y} \\
6 \mathrm{y}\end{array}$ & $\begin{array}{l}\text { Fever } \\
\text { Fever Stroke } \\
\text { Fever Chest pain }\end{array}$ & $\begin{array}{l}\text { Gram positive coccus } \\
\text { Salmonella sp } \\
\text { Non-haemolytic } \\
\text { Streptococcus }\end{array}$ & $\begin{array}{l}\stackrel{?}{?} \\
\text { Tonsil }\end{array}$ & $\begin{array}{l}\text { Necropsy } \\
\text { Necropsy } \\
\text { Clinical, necropsy }\end{array}$ & $\begin{array}{l}\text { Died } \\
\text { Died } \\
\text { Died }\end{array}$ \\
\hline 5 & $58 \mathrm{M}$ & Uncertain* & $\begin{array}{l}\text { Fever Diarrhoea \& } \\
\text { vomiting }\end{array}$ & Salmonella infantis & Gut & Necropsy & Died \\
\hline $\begin{array}{l}6 \\
7\end{array}$ & $\begin{array}{l}59 \mathrm{~F} \\
52 \mathrm{M}\end{array}$ & $\begin{array}{l}\text { At least } 9 y \\
5 y\end{array}$ & $\begin{array}{l}\text { UTI persistent fever } \\
\text { Enteritis fever left } \\
\text { chest pain }\end{array}$ & $\begin{array}{l}\text { Escherichia coli } \\
\text { Salmonella } \\
\quad \text { typhimurium }\end{array}$ & $\begin{array}{l}\text { Urine } \\
\text { Gut }\end{array}$ & $\begin{array}{l}\text { Necropsy } \\
\text { Clinical }\end{array}$ & $\begin{array}{l}\text { Died } \\
\text { Died at } \\
\text { operation }\end{array}$ \\
\hline $\begin{array}{l}8 \\
9\end{array}$ & $\begin{array}{l}54 \mathrm{M} \\
73 \mathrm{M}\end{array}$ & $\begin{array}{r}24 \mathrm{~d} \\
3 \mathrm{w}\end{array}$ & $\begin{array}{l}\text { Fever stroke } \\
\text { Fever CCF }\end{array}$ & $\begin{array}{l}\text { S aureus } \\
\text { Pseudomonas } \\
\text { aeruginosa }\end{array}$ & $\stackrel{?}{\text { Urine }}$ & $\begin{array}{l}\text { Clinical, surgery } \\
\text { Necropsy }\end{array}$ & $\begin{array}{l}\text { Alive } \\
\text { Died }\end{array}$ \\
\hline 10 & $67 \mathrm{M}$ & $2 y$ & Fever & Proteus mirabilis & ? Urine & $\begin{array}{l}\text { Clinical, gallium } \\
\text { scan, surgery }\end{array}$ & Alive \\
\hline
\end{tabular}

*No history or electrocardiographic evidence of myocardial infarction.

MI-myocardial infarction; UTI- urinary tract infection

the antibiotics there was no recurrence of fever and blood cultures were negative. He was discharged home and was well at follow up one month later.

\section{Discussion}

Infected thrombus in a cardiac aneurysm is rarely recognised and only nine cases have been published worldwide. ${ }^{2-10}$ The clinical details of the present case are compared with those of the previous cases in the table. Patients may present from a few weeks to many years after a myocardial infarction with a febrile illness, which either settles initially with antibiotic treatment and recurs later or fails to settle despite appropriate antibiotic treatment. The organisms and the initial source of infection, when known, have varied. In most of the reported cases the diagnosis was made at necropsy. In three recent cases ${ }^{78} 10$ the condition was suspected on clinical grounds and confirmed at surgery, which was successful in two. ${ }^{810}$ In the present case the diagnosis was not suspected before surgery, which was performed because the ventricular aneurysm was causing a low cardiac output and local discomfort rather than because the staphylococcal septicaemia was proving difficult to treat.

Any patient with a left ventricular aneurysm who develops bacteraemia may be at risk of developing an infected mural thrombus. Persistence or recurrence of fever despite appropriate antibiotic treatment should raise suspicion of this diagnosis. Definitive non-invasive diagnosis may be impossible. In one previous case ${ }^{10}$ a gallium 67 citrate scan showed uptake in the region of the cardiac apex. Medical cure of this condition may be difficult even with prolonged parenteral antibiotic treatment and surgical resection of the aneurysm containing the infected thrombus should be undertaken early.

\section{References}

1 Tibbutt DA. True left ventricular aneurysm. Br Med J 1984; 289:450-1.

2 Joffe S, Feil H. Subacute bacterial endocarditis arising in mural thrombi following a myocardial infarction: a case report. Circulation 1955;12:242-6.

3 Decker JP, Clancy CF. Salmonella endocarditis: report of three cases, including one of mural endocarditis. Bull Ayer Clinic Lab 1959;4:1-15.

4 Smirnova DN, Poletaev PA, Levitskaya GD. A case of mural subacute septic endocarditis in a patient with a left ventricular aneurysm. Klin Med (Moskva) 1960;6:143-4.

5 McNally EM, Kennedy RJ, Grace WR. Salmonella infantis infection of a pre-existent ventricular aneurysm. Am Heart $J$ 1964;68:541-8.

6 Castleman B, McNeely BU. Case records of the Massachusetts General Hospital: case 45-1970. N Engl J Med 1970;283:982-90.

7 Catherwood E, Mintz GS, Kotler MN, Kimbiris D, Lemmon W, Parry WR. Pseudoaneurysm of the left ventricle complicated by Salmonella typhimurium infection. Am J Med 1980;68:782-6.

8 McCallum DG, Grow J. Mural thrombus endocarditis complicating an acute myocardial infarction. Arch Intern Med 1981;141:527-8.

9 Schneiderman H, Wolfson M. Pseudomonal abscess formation within a cardiac mural thrombus. Arch Intern Med 1982;142:2194-5.

10 Venezio FR, Thompson JE, Sullivan H, Subramanian R, Ritzman P, Gunnar RM. Infection of a ventricular aneurysm and cardiac mural thrombus. Am J Med 1984;77:551-4. 